Original Article

\title{
SCREENING OF MULTI BIOACTIVE METABOLITES PRODUCING MICROORGANISMFROM GARDEN SOIL OF DR. M. G. R EDUCATIONAL AND RESEARCH INSTITUTE, CHENNAI
}

\author{
SENTHILRAJR, GEJALAKSHMI S., THARUNKUMAR M., SANTHOSH A., LOKESH V., TANISHA B. A. \\ Department of Pharmaceutical Biotechnology, Faculty of pharmacy, Dr. M.G.R. Educational and Research Institute, Chennai-77 \\ Email: senthilrajbt@gmail.com
}

Received: 20 Jan 2020, Revised and Accepted: 19 Mar 2020

\begin{abstract}
Objective: Screening of industrial important bioactive metabolites of Antibiotics, hydrolytic enzymes producing microorganism from garden soil of Dr. M. G. R Educational and Research Institute, Chennai.

Methods: Desired ten soil samples taken and were serially diluted. Crowded plate method used for antibiotic-producing microorganism and Starch agar medium and gelatin medium tests were performed for hydrolytic enzymes (Amylase and Gelatinase).
\end{abstract}

Results: Among the tested soil samples, antibiotic producing microorganisms were not found, but has hydrolytic enzymes amylase and gelatinase. Thus screened soil samples biochemically identified as Bacillus species.

Conclusion: This study concludes that, the collected sample, produced Antibiotic negative result and it's possess other industrial important hydrolytic enzymes. Thus Screening of more bioactive metabolites producing ability from a single isolate, will be more useful for effective screening.

Keywords: Antibiotic activity, Soil microorganisms, Antimicrobial activity and Hydrolytic enzyme

(C) 2020 The Authors. Published by Innovare Academic Sciences Pvt Ltd. This is an open access article under the CC BY license (http://creativecommons.org/licenses/by/4.0/) DOI: http://dx.doi.org/10.22159/ijcpr.2020v12i3.38313. Journal homepage: https://innovareacademics.in/journals/index.php/ijcpr

\section{INTRODUCTION}

Generally plants, animals and marine sources are used for the discovery of new drugs. The current demands of pharmaceuticals are increased more and wide varieties of drug discoveries are ongoing. So the industrial expenses are huge and consuming time [1]. To fulfill the demands, overcoming snags, challenges and safer economics, microorganisms are widely used as source for new drugs. An enormous variety of bioactive metabolites with different therapeutic properties have been isolated from several microbial species due to their rapid growth, constant and eternal source [2-5]. Although number and species of microbes in soil vary directly with environmental conditions like nutrient availability, soil texture, and type of vegetation cover [6]. Screening of antibiotic from soil would be normally practical [7-9] as well as single sample isolates may not possess a positive activity and microbial origin, meet industrial demand [10]. So in this study, we aimed for screening of industrial important bioactive metabolites antibiotics producing micro- organism along with their isolates possesses any industrial important hydrolytic enzymes (Amylase and Gelatinase) producing ability.

\section{MATERIALS AND METHODS}

\section{Collections of soil samples}

The samples were collected from in and around garden soil of Dr. M. G. R Educational and Research Institute, Chennai, India. After the removal of $3.0 \mathrm{~cm}$ of the soil from the surface, the samples were collected upto $20 \mathrm{~cm}$ depth. The soil samples were collected in polyethylene bags, sealed, and stored in a refrigerator. One gm of each soil samples were added to a conical flask containing $100 \mathrm{ml}$ of sterile water. All flasks were shaken for $30 \mathrm{~min}$ at below room temperature [11]. These flasks were considered as stock cultures. All chemicals, media, media components, and other reagents were purchased from (USA), Merck (USA), HiMedia Laboratories (India) etc

Table 1: Soil collected from different area of in and around garden of Dr. M. G. R educational and research institute

\begin{tabular}{ll}
\hline Soil & Area \\
\hline Sample I & Rhizosphere of coconut tree \\
Sample II & Rhizosphere of palm tree \\
Sample III & Rhizosphere of banyan tree \\
SampleIV & Agricultural field \\
Sample V & Rhizosphere of Guava tree \\
SampleVI & Plantation field near industrial area \\
SampleVII & Rhizosphere of Tamarind tree \\
SampleVIII & Rhizosphere of Papaya tree \\
Sample IX & Rhizosphere of mango tree \\
Sample X & Rhizosphere of Ashoka tree \\
\hline
\end{tabular}

\section{Reference strain}

The Reference bacteria used in this study were obtained from National Chemical laboratory, Pune. They include Bacillus Subtilis (NCIM-2063), Bacillus polymyxa (NCIM-2540), Escherichia coli (NCIM-2345) Pseudomonas aeruginosa (NCIM-5029), and Staphylococcus aureus (NCIM-2901).
Screening of antibiotic-producing isolates

A series of culture tubes containing $9 \mathrm{ml}$ of sterile water was taken From the stock culture, $1 \mathrm{ml}$ suspension was transferred aseptically to the tube no: $1\left(10^{-1}\right)$, mixed well. From the tube no: 1 , one ml of suspension was transferred into 2nd tube $\left(10^{-2}\right)$, mixed well. Similarly, dilutions up to $10^{-5}$ were made. From the highest dilution, $0.1 \mathrm{ml}$ of 
suspension from each culture tube was spreaded on sterile Soybean casein digest agar plate. The plates were incubated at $37^{\circ} \mathrm{C}\left( \pm 2{ }^{\circ} \mathrm{C}\right)$ for 3 to $5 \mathrm{~d}$. The plates were observed intermittently during incubation, a clear zone of inhibition around it grown colonies indicates the antibiotic-producing ability of microorganism $[12,13,15)$.

\section{Characterization of isolates}

From the above antibiotic screened plates, a well-isolated colonies were taken their biochemical character were studied [13], Thus isolated soil sample mostly contains Bacillus species which is used for further primary screening of Amylase, and Gelatinase producing ability of microorganism.

\section{Screening of enzyme-amylase by starch agar plate method}

A loopful of previously isolated strains were streaked over the surface of starch agar plates and incubated for $24-48 \mathrm{~h}$ at $37{ }^{\circ} \mathrm{C}$ under static condition in an inverted position. After the period of incubation, the plates were flooded with Logul's solution and a clear area (starch hydrolysis) surrounding the bacterial growth showed positive reaction for extracellular amylase secretion. In contrast, absence of clear zone around bacterial colonies was considered as a non-secretion of a-amylase enzyme [12,13, 16-18).

\section{Screening of enzyme-gelatinase by gelatin liquefaction test}

A loopful of previously isolated strains were stabbed over the gelatin agar and incubated for $48 \mathrm{~h}$ at $35^{\circ} \mathrm{C}$. After the period of incubation, the cultures placed in a refrigerator at $4{ }^{\circ} \mathrm{C}$ until the bottom resolidifies. If gelatin was hydrolyzed, the medium will remain liquid after refrigeration. If gelatin was not hydrolyzed, the medium will resolidify during the time it is in the refrigerator $[12,13]$.

\section{RESULTS}

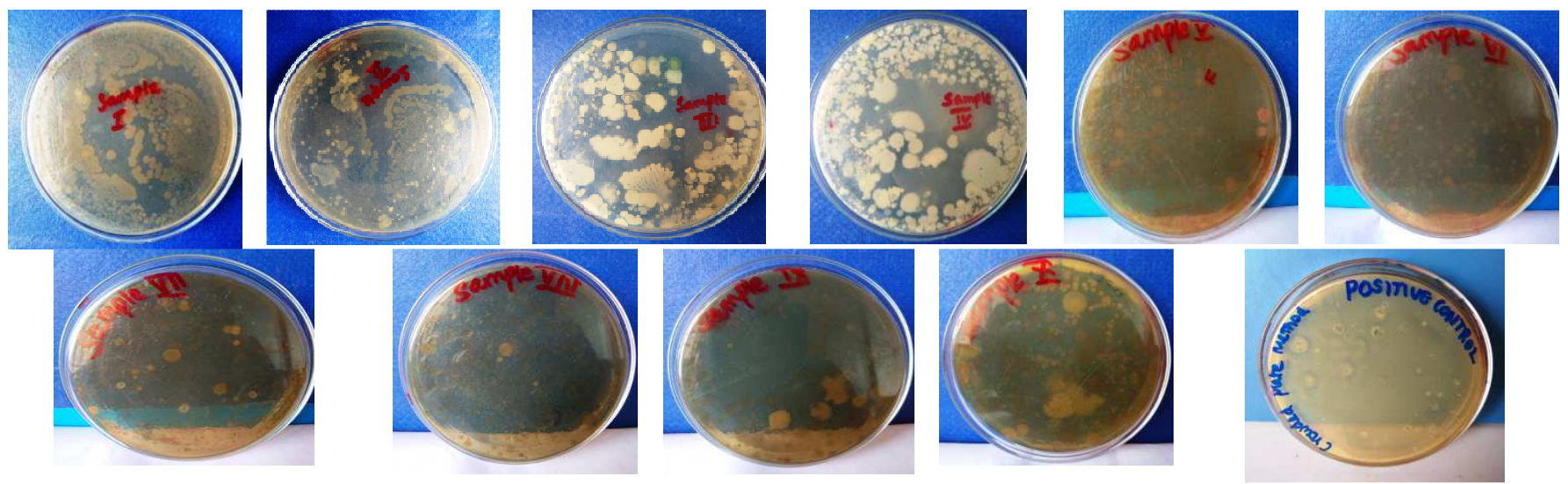

Fig. 1: Growth of microorganism after $48 \mathrm{~h}$ incubation at $37^{\circ} \mathrm{C}$ in Crowded plate method for screening of antibiotic-producing ability of soil sample 1 to 10
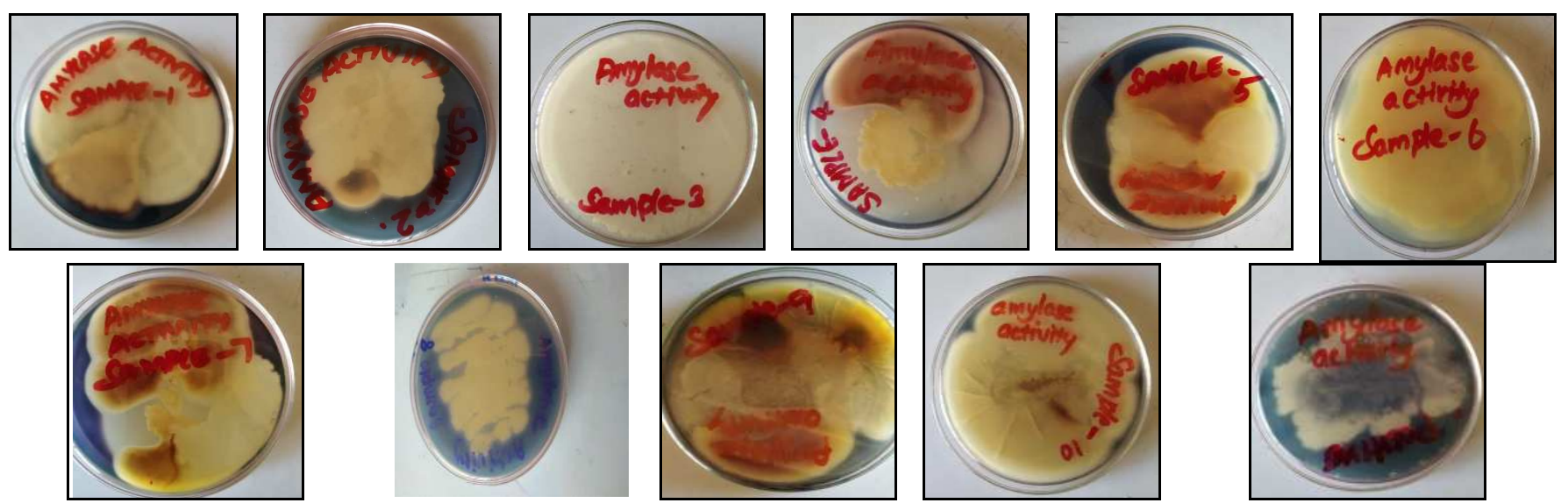

Fig. 2: A clear colourless zone produced around the colonies in starch hydrolysis test

Table 2: Comparison of bioactive metabolites producing ability of the microorganism

\begin{tabular}{lllll}
\hline S. No. & Sample & Antibiotics producing ability & Amylase producing ability & Gelatinase producing ability \\
\hline 1. & Sample I & - & + & + \\
2. & Sample II & - & + & + \\
3. & Sample III & - & + & + \\
4. & Sample IV & - & + & + \\
5. & Sample V & - & + & + \\
6. & Sample VI & - & + & + \\
7. & Sample VII & - & + & + \\
8. & Sample VIII & - & + & + \\
9. & Sample IX & - & + & + \\
10. & Sample X & - & + & + \\
11. & Control & + & + & + \\
\hline
\end{tabular}

(+) Present, (-) Absent 


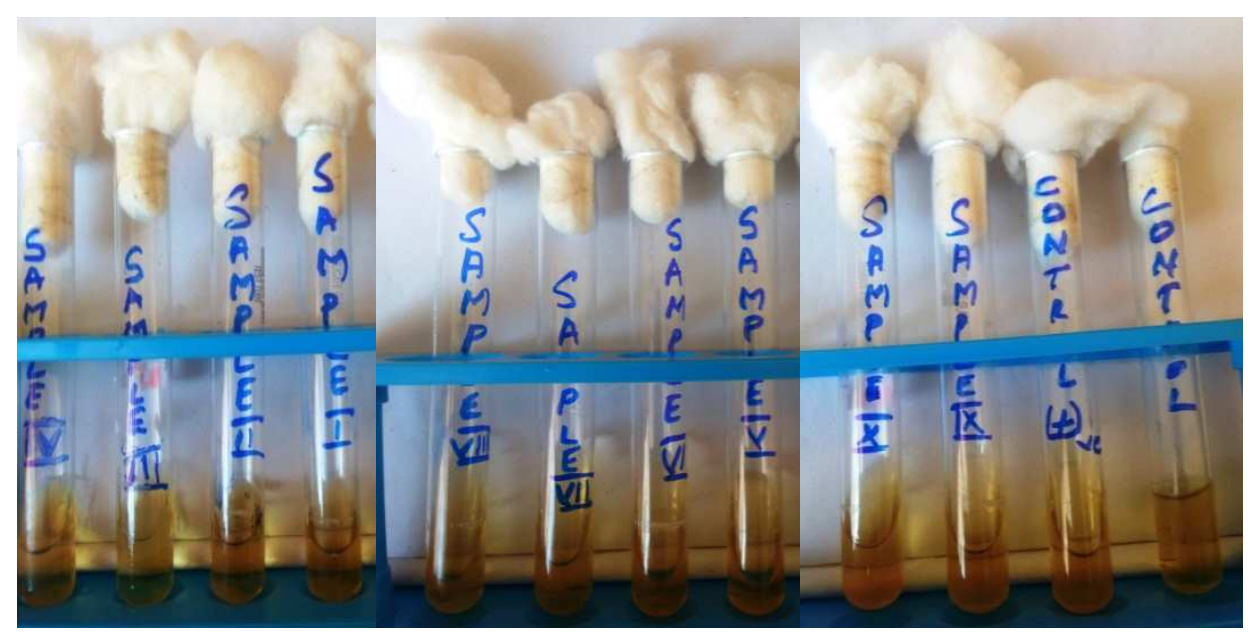

Fig. 3: liquefaction of gelatin after placed at $4{ }^{\circ} \mathrm{C}$ in gelatin hydrolysis test

\section{DISCUSSION}

The randomly selected soil samples for isolation of antibioticproducing micro-organisms were studied by crowded plate method. All the $10^{-5}$ serially diluted ten samples, after $72 \mathrm{~h}$ incubation at 37 ${ }^{\circ} \mathrm{C}$ not produced any clear zone around the developed colonies, the growth was found as shown in the fig no: 1 . Further to observe the effect of time duration extension, on secondary metabolites antibiotics, producing ability of microorganism were monitored [11, $19,20]$ in all the plates which were incubated up to $5 \mathrm{~d}$ at $37^{\circ} \mathrm{C}$. Even though the increased incubation period of all soil sample does not have no effect on producing a clear zone, there is no large variation between the $3 \mathrm{~d}$ and $5 \mathrm{~d}$ kept samples for the antibioticproducing ability of microorganisms.

Table 3: Biochemical characteristics of the microorganism

\begin{tabular}{|c|c|c|c|c|c|c|c|c|c|c|c|c|}
\hline $\begin{array}{l}\text { S. } \\
\text { No. }\end{array}$ & $\begin{array}{l}\text { Biochemical } \\
\text { character }\end{array}$ & $\begin{array}{l}\text { Sample } \\
1\end{array}$ & $\begin{array}{l}\text { Sample } \\
1\end{array}$ & $\begin{array}{l}\text { Sample } \\
1\end{array}$ & $\begin{array}{l}\text { Sample } \\
1\end{array}$ & $\begin{array}{l}\text { Sample } \\
1\end{array}$ & $\begin{array}{l}\text { Sample } \\
1\end{array}$ & $\begin{array}{l}\text { Sample } \\
1\end{array}$ & $\begin{array}{l}\text { Sample } \\
1\end{array}$ & $\begin{array}{l}\text { Sample } \\
1\end{array}$ & $\begin{array}{l}\text { Sample } \\
1\end{array}$ & Control \\
\hline 1. & Gram staining & + & + & + & + & + & + & + & + & + & + & + \\
\hline 2. & Endospore & + & + & + & + & + & + & + & + & + & + & + \\
\hline 3. & motility & + & + & + & + & + & + & + & + & + & + & + \\
\hline 4. & Indole test & - & - & - & - & - & - & - & - & - & - & - \\
\hline 5. & Methyl red & - & - & - & - & - & - & - & - & - & - & - \\
\hline 6. & VogesProskauer & + & + & + & + & + & + & + & + & + & + & + \\
\hline 7. & $\begin{array}{l}\text { Citrate } \\
\text { utilization }\end{array}$ & + & + & + & + & + & + & + & + & + & + & + \\
\hline 8. & Oxidase & \pm & \pm & \pm & \pm & \pm & \pm & \pm & \pm & \pm & \pm & \pm \\
\hline 9. & Urease test & - & - & - & - & - & - & - & - & - & - & - \\
\hline
\end{tabular}

(+) Positive reaction (-) Negative reaction ( \pm ) Variable reaction

From the above table 3 biochemical test all the isolated test samples were confirmed as Bacillus species.

As shown in the fig. 2 Logul's solution flooded starch agar plates produces absence of blue colour around the colonies, which indicate the soil isolate has bioactive metabolite amylase producing ability microorganism. Among the tested microorganism the sample III, IV and IX produces wide clear zone, which indicates the organism has more effect on amylase producing ability. The remaining all samples have moderate effect on amylase producing ability when compared to control.

In the present study, an attempt was made to isolate wild type of gelatinase enzyme-producing strains and their ability was as shown in the fig. 3 . all the incubated tubes after maintaining the temperature below $4{ }^{\circ} \mathrm{C}$ produced liquefaction which indicates the isolated microorganism has gelatinase enzyme producing ability. The above results clearly showed that the collected sample from different places of garden soil of our institute has large number of gelatinase enzyme producing ability bacteria, which might be due to richness of nutrients.

\section{CONCLUSION}

Industries are in a compulsion to fulfill their requirements within shorter duration by using cheaper material. Even though soil source is cheaper, in some cases a single isolates may not possess the specific bioactive metabolites, but the industrial demands are increased huge in size. This study concludes that the collected sample contains absence of Antibiotic isolates, which possess other industrial important bioactive hydrolytic enzymes amylase and gelatinase. So a single organism may possess more number of bioactive metabolites.

\section{ACKNOWLEDGMENT}

The first author Senthilraj. $\mathrm{R}$ is thankful to our management of Dr. M.G.R. Educational and Research Institute, Chennai, for providing facilities required for the successful completion of the research work.

\section{FUNDING}

Nil

\section{AUTHORS CONTRIBUTIONS}

All the authors have contributed equally

\section{CONFLICT OF INTERESTS}

The authors declared that they have no conflict of interest

\section{REFERENCES}

1. David Taylor. The pharmaceutical industry and the future of drug development. In. Pharmaceuticals in the Environment; 2015. p. 1-33.

2. Abbas S, Senthilkumar R, Arjunan S. Isolation and molecular characterization of the microorganism producing novel antibiotics from the soil sample. Eur J Exp Biol 2014;4:149-55.

3. Berdy J. Bioactive microbial metabolites. J Antibiot 2005;58:1-26. 
4. JJ Sanglier, H Haag, TA Huck, T Fehr. Review of actinomycetes compounds: 1990-1995. Expert Opin Invest Drugs 1996;5:207-23.

5. Waksman SA. Classification, identification and description of genera and species: The Actinomycetes. Vol. 2. Baltimore: Williams and Wilkins; 1961. p. 1-363.

6. Nino A Gagelidze, Lia L Amiranashvili, Tinatin A Sadunishvili, Giorgi I Kvesitadze, Tengiz F Urushadze, Tamar 0 Kvrivishvili. Bacterial composition of different types of soils of Georgia. Annals Agrarian Sci 2018;16:17-21.

7. Arifuzzaman M, Khatun MR, Rahman H. Isolation and screening of actinomycetes from sundarbans soil for antibacterial activity. Afr J Biotechnol 2011;9:4615-9.

8. Kurtboke DI, Chen CF, Williams ST. Use of polyvalent phage for reduction of streptomycetes on soil dilution plates. J Appl Bacteriol 1992;72:103-11.

9. Vineeta Singh, Shafiul Haque, Harshita Singh, Jyoti Verma, Kumari Vibha, Rajbir Singh, et al. Tripathi, isolation, screening, and identification of novel isolates of actinomycetes from India for antimicrobial applications. Front Microbiol 2016;7:19-21.

10. Pandey A, Nigam P, Soccol CR, Soccol VT. Advances in microbial amylases. Biotechnol Appl Biochem 2000;31:135-52.

11. Casida LE. Industrial microbiology. 3rd edition. Wiley Easter Ltd; 1984. p. 3-437.
12. James G. Cappuccinoand natalie sherman microbiology a laboratory manual. $10^{\text {th }}$ edition. Pearson Education; 2014. p. 352-7.

13. Aneja KR. Experiments in microbiology, plant pathology and biotechnology, new age international private limited, Publishers, New delhi; 2010.

14. Bergeys manual of determinative bacteriology. 9th edition. The williams and Wilkins 428 East Preston street Baltimore, Maryland 21202, USA; 1994.

15. Berdy J. Recent advances in and prospects of antibiotic research. Process Biochem 1980;15:28-36.

16. Kori, MA Halkai. Pharmaceutical biotechnology fundamentals and applications; 2000. p. 140-60.

17. Sivaramakrishnan S. $\alpha$-amylases from microbial sources-an overview on recent developments. Food Technol Biotechnol 2006;44:173-84.

18. S Wang, C Lin, Y Liu, Z Shen, J Jeyaseelan, W Qin. Characterization of a starch-hydrolyzing $\alpha$-amylase produced by aspergillus niger WLB42 mutated by ethyl methanesulfonate treatment. Int J Biochem Mol Biol 2016;7:1-10.

19. Demain AL. Pharmaceutically active secondary metabolites of microorganisms. Appl Microbiol Biotechnol 1999;52:455-63.

20. Kathryn ER Davis, Shayne J Joseph, Peter H Janssen. Effects of the growth medium, inoculum size, and incubation time on culturability and isolation of soil bacteria. Appl Environ Microbiol 2005;71:826-34. 